https://doi.org/10.31470/2706-7904-2021-16-23-31

\title{
THE PLIGHT IN FOREIGN LANGUAGE LEARNING IN TUNISIAN \\ CONTEXT: CLASSROOM LANGUAGE ASSESSMENT V.S FOREIGN LANGUAGE LEARNING ANXIETY
}

Труднощі у вивченні іноземних мов у туніському контексті: оцінка рівня володіння мовою в класі v.s. тривоги при вивченні іноземних мов

\author{
Leila Najeh Bel'Kiry \\ Ph. Doctor \\ Sfax University (Tunisia, North Africa) \\ najeh.leila@yahoo.com
}

\begin{abstract}
The assessment of language proficiency from a psycholinguistics perspective has been a subject of considerable interest. Many literatures are devoted for the explanation of certain psychological phenomena related to first language acquisition and foreign language learning like language disorders/impairments, critical/sensitive period and language anxiety.

This paper sheds the light on foreign language anxiety, which is in my conviction the hardest problem that concerns the foreign language learner as well as the teacher. The origin of this conviction is that foreign language anxiety hampers learner performance on one hand, and on the other hand effects, negatively, the classroom language assessment which in turn sharpens learner's anxiety more and more. There is a significant negative correlation between foreign language anxiety and classroom language assessment.

Three issues are to be tackled in this paper: (i) The implication of 'anxiety' as a psychological issue in foreign language learning, (ii) classroom language assessment in Tunisian schools and (iii) the relation between foreign language anxiety and classroom language assessment.
\end{abstract}

Key words: classroom language assessment, foreign language learning, language anxiety, Tunisian schools.

\section{Introduction} Bcmyn

Many researches in foreign learning are conducted so as to explain two phenomena related to the language learner.

Which is the origin of the dark impression regarding learning a foreign language?

Why some language learners are more successful than others are? 
These inquiries are set in a context of radical rectification in the FLT scope and the shift from the teacher-centered approach to the learner-centered approach. Lopéz (1996) claimed:

"In the past, the most questions frequently asked which is the best methodology. Now teacher asks know can my student best learn the language, the focus was shifted from the teacher to the learners. This has come the realization that each learner is individual with distinct needs learning styles, mental schemata and attitudes. And to further complicated matters not only different style, but an individual learners utilize different approaches to learning at different stages in the learning process" (p. 10).

In this context, surrounding disciplines, mainly psycholinguistics is involved in foreign language researches. Psycholinguists advocated that in a classroom where the atmosphere is friendly, SECURE and supportive, students are more willing to take RISKS in using the new language (Sun, 2012).

In this vein, some foreign language teaching approaches like the affective humanistic approach which has a psychological underpinning was developed "to help the learner to develop his own personality and mind to respond to his PERSONAL FEARS and needs and encourage his emotional and social development” (Cook, 1994: 30-31).

Such as an approach, also depicted as clinical methods (Balboni, 2006, p.45), gives importance to the FEELING and EMOTIONS of the learners. The proponents of this approach presume that a learner must be liberated from NEGATIVITY caused by ANXIETY and pessimistic impression regarding learning a foreign language by creating an encouraging atmosphere (Freeman, 2000: 73; Lopéz, 1996: 14).

\section{Purpose of the study}

The ultimate aim of this article is to explore the correlation between foreign language learning anxiety and classroom language assessment in Tunisian preparatory schools.

\section{Research questions and hypothesis}

The research seeks to answer two vital questions:

What kind of relation is between classroom language assessment and foreign language learning anxiety?

In what sense does classroom language assessment aggravate learner anxiety? The two questions presuppose a negative correlation between classroom language assessment and foreign language learning anxiety. In other words, classroom language assessment elevates anxiety.

The direct requirement of the hypothesis is that the scores, the foreign language learners got, do not, always, reflect their real/true level taking into account language anxiety. 


\section{Literature review}

Аналіз літератури

\section{The implication of 'anxiety' as a psychological issue in}

\section{foreign language learning}

Language disorders, language impairments, language anxiety and many related terms are currently used in foreign language learning literatures. Actually, in the realm of foreign language learning, such concepts are 'extraneous', they are borrowed from other disciplines mainly psycholinguistics, psychology and sociology that get involved in FL researches since late 1970's. Kramsch (2000) noted that "It is evident to any one reading research in second language acquisition, that the field as inter-disciplinary. The study of second language acquisition can be linguistic, psycholinguistic, sociolinguistic, sociological, psychological and educational (p. 1). Thus, foreign language researches have seen phenomenal growth in the involvement of various disciplines like psychology, sociology, anthropology, finally foreign language learning is placed at the heart of different disciplines.

This paragraph reviews some preliminaries about foreign language learning anxiety by answering the following inquiries: What is meant by foreign language learning anxiety? And what is its origin?

Wilson (2006) differentiated between general anxiety and academic anxiety.

In one context, general anxiety is thought of as a psychological phenomenon that concern human mood in everyday life.

In a second context, academic anxiety referred to psychological trouble associated with learning context in general and not limited to foreign language learning. Tran (2012) claimed "Research has shown that anxiety is not uncommon in almost all disciplines of learning" (p. 69). Wilson (2006: 44) mentioned many types of academic anxiety as much as school subjects, such as math anxiety, second language anxiety that is referring to "the feeling of tension and apprehension specifically associated with second language contexts, including speaking, listening and learning" (MacIntyre \& Gardener, 1994: 282).

In foreign language learning realm, relying on Hamilton Anxiety Rating Scale, Horwitz et al. (1986) developed the foreign Language Classroom Anxiety Scale (FLCAS), Horwitz et al., as cited in MacIntyre \& Gardner, 1994: 286).

Spielberger (1983) elaborated the State-Traits-Anxiety-Inventory (STAI) as a tool to assess foreign language anxiety Such scales measure the degree of anxiety throughout three different stages of language learning: (i) Input anxiety scale: determines the degree of learner's trouble when taking information in FL; (ii) Processing anxiety scale, measures the level of anxiety when thinking in FL; (iii) Output anxiety refers to the apprehension experienced when speaking or writing in FL (MacIntyre \& Gardner, 1994: 289). 
Thus FLL anxiety is marked in all language skills: speaking, listening, writing and reading as demonstrated in the following figure 1.

\section{Figure 1}

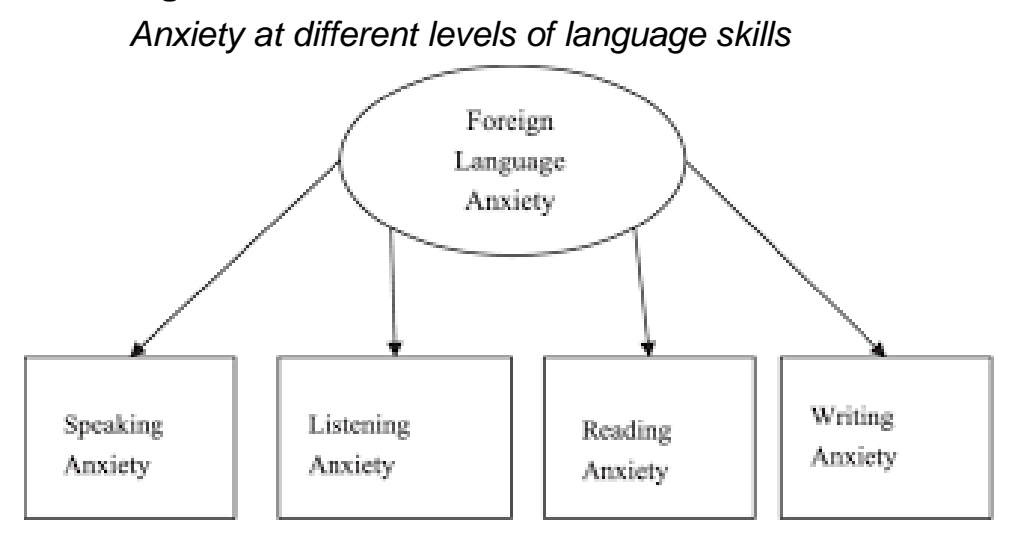

Such empirical studies deduce two things: (i) rate of anxiety is more aggravated in FLL than in other academic discipline (Tran, 2012: 70). Tóth (2011) commented on that "What makes this anxiety, called foreign language anxiety (FLA), different from other academic anxieties is a unique metacognitive element, which manifests itself in learners' awareness that "deprived" of their normal means of communication (i.e., the L1) they are to communicate via a language in which they do not have full competence (p. 40).

The degree of anxiety is constant during the learning stages. Tanveer (2007) claimed that "All the three stages of anxiety are somewhat interdependent; each stage depends on the successful completion of the previous one" (ibid., p. 23). More important, anxiety as a psychological traits, is an affective factor in foreign language that always cripples the learning process.

\section{Classroom Language assessment}

Cheng and Fox (2017) defined classroom language assessment a complex evaluative practice that requires teachers to make judgments about student learning, using a numerical (e.g., 80\%) or ordinal (e.g., A, B, C) scale. Actually, in my belief, this judgment may aggravate language anxiety.

Still further, Cheng (2014) discriminated between two types assessments: (i) assessment of learning happens after learning in order to see whether learning has actually taken place; (ii) assessment for learning is a process of determining where the student is in the right learning process. The two assessments provide available information for the teacher and student to reach some goals. In the same direction, formative and summative is another dichotomy depicting assessment throughout the learning process. Like assessment of learning and assessment for learning, formative and summative assessments 
constitute a binary. The following graph shows the continuity and the convergence between the two types of assessments adopted from (Khalifa, Baccari, Souilem \& Neji, 2018).

\section{Figure 2}

The contiguity between formative and summative assessment

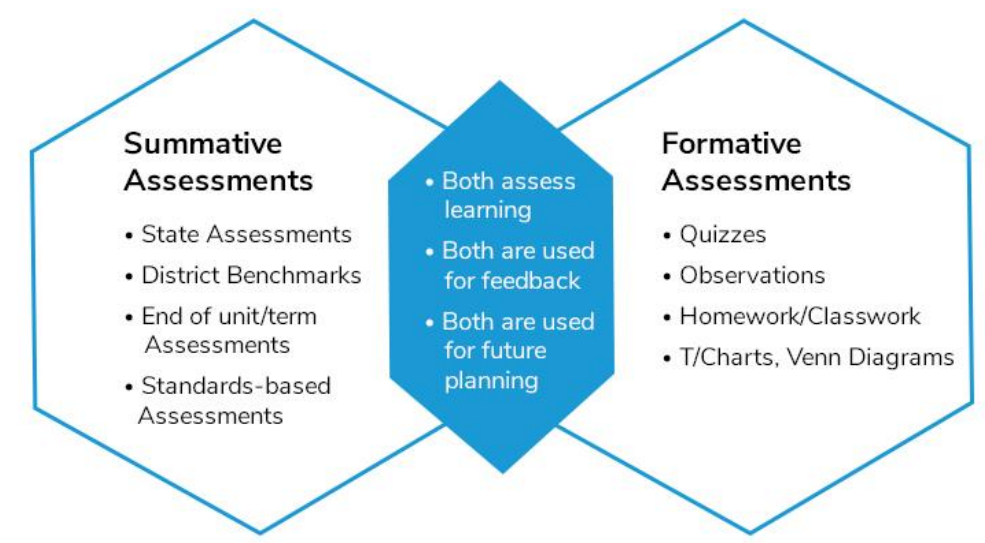

In the same direction, Taylor and Nolen (2005) proposed four fundamental aspects of classroom assessment: events, tools, processes, and decisions.

The events and decisions explain the rationale behind the assessment i.e why assessment is being conducted; they help instructors self-evaluate their assessment techniques.

Tools are not only the variety of methods which can be used in assessment for different communication skills reading, writing, speaking, and listening, but they also refer to the sources from which the assessments come (e.g., teacher-created material, material found on the internet, material dictated by a governing school body).

The processes of assessment that deals with what to teach and assess, and how to reinforce the assessment.

In Tunisian context, in secondary and preparatory school's learners are assessed twice a trimester. The first assessment could be called formative assessment conducted, daily, during the learning process and at the end of some units. The second is a summative assessment held at the end of each trimester.

\section{Research method \\ Методи дослідження}

\section{Participants}

The target population in this study is 95 Tunisian pupils enrolled in Tunisian public schools. The subjects aged between 13 and 17 are classified into three level groups(i) group include $317^{\text {th }}$ year pupils; (ii) group two $8^{\text {d }}$ include 30 year pupils and (iii) group three made up of $349^{\text {th }}$ year pupils. 
In Tunisian Educational system, English is taught as a foreign language in elementary public schools for $4^{\text {th }}$ level pupils as well as in preparatory and secondary schools.

\section{Instrument}

The matched-guised technique was originally developed to investigate people's attitudes toward social, geographical or ethnic language varieties and to the different languages spoken in bilingual communities (Lambert, 1960).

To explore the way classroom language assessment aggravates learner's anxiety which in turn affects learner's performance, both disguised and undisguised, the two subtypes of the matched-guise techniques, have been opted to collect data.

While, disguised techniques is used to collect data from the pupils who are unaware that they are being assessed, the undisguised technique is used to collect from learners who are aware they are tested. Generally, this technique aims at evaluating the real, the true level of the learners, however in this research it aims at revealing the relation between anxiety and classroom language assessment.

The data were collected in the last trimester of the academic (2020-2021). The corpus consists of English tests prepared by English teachers to assess Tunisian pupils in public schools. It consists of a reading comprehension passage, language tasks and writing.

\section{Discussion}

\section{Дискусії}

\section{Table 1}

Findings obtained through disguised and Undisguised techniques

\begin{tabular}{|c|c|c|c|c|c|c|}
\hline \multirow[b]{2}{*}{ Level } & \multicolumn{3}{|c|}{$\begin{array}{l}\text { Disguised techniques/Pupils unaware they are } \\
\text { being tested }\end{array}$} & \multicolumn{3}{|c|}{$\begin{array}{l}\text { Undisguised techniques/ pupils aware, they are } \\
\text { being tested }\end{array}$} \\
\hline & $\begin{array}{l}\text { Mark/score } \\
(5 \text { and } 10)\end{array}$ & $\begin{array}{l}\text { Mark/score } \\
(10 \text { and } 15)\end{array}$ & $\begin{array}{l}\text { Mark/score } \\
(15 \text { and 20) }\end{array}$ & $\begin{array}{l}\text { Mark/score } \\
(5 \text { and } 10)\end{array}$ & $\begin{array}{l}\text { Mark/score } \\
(10 \text { and } 15)\end{array}$ & $\begin{array}{l}\text { Mark/score } \\
(15 \text { and } 20)\end{array}$ \\
\hline \multirow[t]{2}{*}{$7^{\text {th }}$} & $\begin{array}{l}\text { Number of } \\
\text { pupils: } 4\end{array}$ & $\begin{array}{l}\text { Number of } \\
\text { pupils : } 17\end{array}$ & $\begin{array}{l}\text { Number of } \\
\text { pupils: } 10\end{array}$ & $\begin{array}{l}\text { Number of } \\
\text { pupils: } 8\end{array}$ & $\begin{array}{l}\text { Number of } \\
\text { pupils: } 16\end{array}$ & $\begin{array}{l}\text { Number of } \\
\text { pupils: } 7\end{array}$ \\
\hline & $\begin{array}{l}\text { Percentage: } 12 \\
.9\end{array}$ & $\begin{array}{l}\text { Percentage: } \\
54.83\end{array}$ & $\begin{array}{l}\text { Percentage: } \\
32.25\end{array}$ & $\begin{array}{l}\text { Percentage: } \\
25.8\end{array}$ & $\begin{array}{l}\text { Percentage: } \\
51.6\end{array}$ & $\begin{array}{l}\text { Percentage: } \\
22.5\end{array}$ \\
\hline \multirow[t]{2}{*}{$8^{\text {th }}$} & $\begin{array}{l}\text { Number of } \\
\text { pupils :3 }\end{array}$ & $\begin{array}{l}\text { Number of } \\
\text { pupils: } 16\end{array}$ & $\begin{array}{l}\text { Number of } \\
\text { pupils: } 11\end{array}$ & $\begin{array}{l}\text { Number of } \\
\text { pupils: } 6\end{array}$ & $\begin{array}{l}\text { Number of } \\
\text { pupils: } 15\end{array}$ & $\begin{array}{l}\text { Number of } \\
\text { pupils: } 9\end{array}$ \\
\hline & Percentage: 10 & $\begin{array}{l}\text { Percentage: } \\
53.33\end{array}$ & $\begin{array}{l}\text { Percentage: } \\
36.66\end{array}$ & $\begin{array}{l}\text { Percentage: } \\
20\end{array}$ & Percentage: & $\begin{array}{l}\text { Percentage: } \\
30\end{array}$ \\
\hline \multirow[t]{2}{*}{$9^{\text {th }}$} & $\begin{array}{l}\text { Number of } \\
\text { pupils: } 4\end{array}$ & $\begin{array}{l}\text { Number of } \\
\text { pupils: } 18\end{array}$ & $\begin{array}{l}\text { Number of } \\
\text { pupils: } 12\end{array}$ & $\begin{array}{l}\text { Number of } \\
\text { pupils: } 7\end{array}$ & $\begin{array}{l}\text { Number of } \\
\text { pupils: } 17\end{array}$ & $\begin{array}{l}\text { Number of } \\
\text { pupils: } 10\end{array}$ \\
\hline & $\begin{array}{l}\text { Percentage: } 11 \\
.76\end{array}$ & $\begin{array}{l}\text { Percentage: } \\
52.94\end{array}$ & $\begin{array}{l}\text { Percentage: } \\
35.29\end{array}$ & $\begin{array}{l}\text { Percentage: } \\
20.58\end{array}$ & $\begin{array}{l}\text { Percentage: } \\
50\end{array}$ & $\begin{array}{l}\text { Percentage: } \\
29.41\end{array}$ \\
\hline
\end{tabular}

The table summarizes the data for two formative assessments during the last trimester of the academic year 2020-2021. Though the pupils were informed about the test, when the undisguised technique is used to collect the data, a significant difference is found between the data collected through disguised and undisguised techniques. The findings show that 
marks obtained when the learners are unaware, they being tested is better than when they are aware. When they aware they they are being tested $54.83 \% 7^{\text {th }}$ year pupils, $53.33 \%$ of 8th year pupils scored between 5 and 10 marks however the this percentage declined when they are unaware they being tested.

This difference is explained by the fact that when they feel they are controlled they feel worried and anxious, however when they are certain that they are not controlled and they are being assessed they feel comfortable.

This findings have one explanation that learner's anxiety is not a TRAIT ANXIETY as a permanent psychological hallmark, and not limited to particular situation or context. It is "a constant condition without time limitation "(Levit, 1980: 11 as cited in Wilson, 2006: 42), but it a STATE ANXIETY, as a feeling and not an enduring characteristics of an individual's personality" (Wilson, 2006: 42). Also, the findings coincide with other researches, the relevant literature reported that anxious language students study more than relaxed students but their achievement does not reflect that effort (Horwitz et al., 1986; Price, 1991 as cited in MacIntyre \& Gardner, 1994: 286).

In this manner, the marks, the pupils got, fluctuates in accordance with the degree of anxiety which in turn aggravated by the learner's' awareness of being assessed or tested. Actually, the findings are not surprising, taking into account that the context is one among other causes that elevates anxiety Tanveer (2007).

The term context used to show the interface between language anxiety and classroom assessment, is used in its pragmatic meaning, as introduced in pragmatic and discourse literature referring to any relevant characteristics of the setting or environment in which a linguistic unit is systematically used (Huang, 2007: 13). Relying on Cutting \& Fordyce (2002: 3) differentiation between three sorts of context (i) the situational context, what the speakers know about what they can see around them (ii) the background knowledge, what they know about each other and about the world (iii) context and co text what they know about they have been saying, the findings could be understand, why learners' marks is much better than when they are unaware of being assessed.

The CONTEXT of being ASSESSESSED OR TESTED in a specific PLACE, the classroom, and being tested by a SPECIFIC PERSON, the teacher, have a great impact on the learner's responses. In this vein, Tóth (2011) mentioned language classes vs. real-life situations, the teacher, classmates as three contextual elements aggravating FLL anxieties (pp. 36-37). For that reason, it is useful in relation to the discussion of classroom language assessment to have on over the view on the way these variable affects learners' responses for fear of getting weak marks because fear of bad evaluation is, indeed, the apprehension about other people's evaluations (Lucas, Miraflores \& Go, 2011: 102). 
Therefore, language anxiety is the DIRECT cause effecting the proficiency of language learners, however classroom assessment and testing is the INDIRECT cause that elevates that anxiety. To put it another way, anxiety is not a PROBLEM in ITSELF, as long as classroom assessment and testing trigger anxiety.

\section{Conclusions}

Висновки

This research has investigated the corpora of English language learners, collected during the last trimester of the academic year 2020-2021. On the first occasion, the disguise technique is used in collecting data in the sense that the pupils do not that they are being tested, while on the second, undisguised technique is adopted pupils are aware they are being assessed. A significant difference is found between the data collected through disguised and undisguised techniques. The findings show that marks obtained when the learners are unaware, they being tested are better than when they are aware.

Accordingly, anxiety is not the unique factor that handicap foreign language learners' performance. The present study shows that classroom language assessment aggravates learner's anxiety. And higher level of anxiety affects the learning process and lowers down learning performance.

On this basis, this study suggests the PREVENTION of scoring in classroom language assessment is the most effective techniques to help learners get rid of FL learning anxiety in classroom situation.

At the end of this paper I wonder why, researches dealing with language anxiety are always learner-centered, and classroom language assessment is called language or teachers centered while classroom language assessment and foreign language anxiety are interdependent. I suggest that a CORRELATIONAL STUDY is demanded to look for the relationship between foreign language learning anxiety and classroom language assessment. Actually, I do not suppose that such a study can tell us how to deal with the problem of language anxiety, but at least it will be able to unveil one of the its major origins.

\section{References \\ Jimepamypa}

Cheng, L. (2014). Language classroom assessment. TESOL International Association.

Cheng, L., \& Fox, J. (2017). Assessment in the language classroom: Teachers supporting student learning. Palgrave.

Cutting, J., \& Fordyce, K. (2020). Pragmatics: a resource book for students. Routledge. https://doi.org/10.4324/9781003010043 
Huang, Y. (2007). Pragmatics. New York, NY: Oxford University Press.

Khalifa, W.B., Baccari, S., Souilem, D., \& Neji, M. (2018, May). Educational Assessment: Pupils' Experience in Primary School (Arabic Grammar in 7th Year in Tunisia). In International Conference on Intelligent Interactive Multimedia Systems and Services (pp. 410-418). Springer, Cham. https://doi.org/10.1007/978-3-319-59480-4_41

Kramsch, C. (2000). Second language acquisition, applied linguistics, and the teaching of foreign languages. The Modern Language Journal, 84(3), 311-326. https://doi.org/10.1111/0026$\underline{7902.00071}$

Lopéz, C.C. (1996). The role of the teacher in today's language classroom. In T. Kral (Ed.), Teaching development making the right moves (pp. 9-18). Washington: United States information agency.

Lucas, R.I., Miraflores, E., \& Go, D. (2011). English language learning anxiety among foreign language learners in the Philippines. Philippine ESL Journal, 7(94-119).

MacIntyre, P.D., \& Gardner, R.C. (1994). The subtle effects of language anxiety on cognitive processing in the second language. Language learning, 44(2), 283-305. https://doi.org/10.1111/j.1467-1770.1994.tb01103.x

Tanveer, M. (2007). Investigation of the factors that cause language anxiety for ESL/EFL learners in learning speaking skills and the influence it casts on communication in the target language (master's thesis). Retrieved from file:///C:/Users/asus/Downloads/Investigatingthefactorsthatcauselangaugeanxiety.pdf

Taylor, C.S., \& Nolen, S.B. (2005). Classroom assessment: Supporting teaching and learning in real classrooms. Prentice Hall.

Tóth, Z. (2011). Foreign language anxiety and advanced EFL learners: An interview study. WoPaLP, 5, 39-57.

Tran, T.T.T. (2012). A Review of Horwitz, Horwitz and Cope's Theory of Foreign Language Anxiety and the Challenges to the Theory. English Language Teaching, 5(1), 69-75. https://doi.org/10.5539/elt.v5n1p69

Wilson, J.T.S. (2006). Anxiety in Learning English as a Foreign Language: Its Associations with Student Variables, with Overall Proficiency, and with Performance on an Oral Test. Doctoral dissertation. http://digibug.ugr.es/bitstream/10481/1074/1/16235290.pdf 